\title{
Analisis Kebutuhan Tenaga Berdasarkan Beban Kerja Sebagai Dasar Perencanaan SDM Di Instalasi Farmasi RS. X Semarang
}

\author{
Bagus Ronggonundarmo*, Sutopo Patria Jati**, Farid Agushybana** \\ *RS. Permata Medika Semarang, \\ ** Fakultas Kesehatan Masyarakat Universitas Diponegoro, Semarang \\ Email : bagusroonkgo@gmail.com
}

\section{Abstract}

Since X Hospital had an imbalance number of prescriptions and pharmacy technicians, patients often complaints on prescription waiting time which was high up to $58,10 \%$ in 2016 and $45,65 \%$ in 2017. This study aimed to analyze whether workload given is balance with the number of human resources, and it also identified some obstacles in providing the ideal number of human resources.

This was descriptive study with qualitative methods through an in-depth interview and direct observation. The key informans are pharmacist and pharmacy technicians, and the triangulated informans involve the Head of Medical Support Division, the Head of Human Resource, and the Hospital Director. The data of workload were analyzed using WISN (workload indicators of staffing needs) method.

Results explained that the Pharmacy Unit of $X$ Hospital lacks human resources. According to WISN method, there are 11.15 outpatient pharmacy technicians needed by the unit. Recently, the Outpatient Pharmacy Unit has 9 pharmacy technician and need to add 2 more pharmacy technicians. In the Inpatient Pharmacy Unit, there are 11.11 pharmacy technicians required. Only 10 pharmacy technicians work in the Unit, so there is one more pharmacy technician required. In the Drug Storage Unit, only one more pharmacy technician is needed. Fulfilling human resources in the Pharmacy Unit is still difficult because of cost efficiency and inadequacy of work duration. However, the Hospital has designed a new information management system to improve the resource effectiveness.

To sum up, the number of resources in the Pharmacy Unit of X Hospital is lacking. It is suggested that they should arrange work schedule, provide adequate facilities in general and specifically for pharmaceutical purposes, and apply other alternatives to increase the effectiveness of human resources.

Keywords : Human Resources, HR Planning, WISN, Pharmacy.

\section{PENDAHULUAN}

Upaya kesehatan merupakan semua aktivitas yang ditujukan untuk memelihara dan meningkatkan kesehatan sehingga akan mewujudkan derajat kesehatan yang baik dan optimal kepada masyarakat ${ }^{1}$. Ketersediaan sumber daya manusia yang sesuai dengan kebutuhan yang memiliki kemampuan dan kualitas yang tinggi, professional sesuai dengan tugas serta fungsinya merupakan indikator keberhasilan pengelolaan farmasi yang efektif dan efisien di rumah sakit ${ }^{2}$. Setiap tahunnya terjadi peningkatan jumlah resep yang dilayani di farmasi namun peningkatan pelayanan resep ini tidak diimbangi dengan penambahan jumlah tenaga sehingga terjadi peningkatan beban kerja di farmasi. Peningkatan beban kerja ini membuat waktu tunggu obat jadi menjadi lebih lama dari indikator mutu 
yang ditetapkan oleh rumah sakit sehingga komplain pasien terhadap pelayanan farmasi meningkat.

Dari data kepegawaian disebutkan bahwa tenaga farmasi tahun 2016 sebanyak 22 tenaga yang terdiri dari 1 apoteker, 19 asisten apoteker dan 2 petugas di gudang farmasi. Dengan jumlah resep yang dilayani sebanyak 83.868 resep ditahun 2016. Pada tahun 2017 dengan peningkatan jumlah resep menjadi 84.291 dilayani oleh 22 orang petugas farmasi yang terdiri dari 2 apoteker, 19 asisten apoteker dan 1 petugas gudang farmasi ${ }^{3}$.

Data dari Humas Marketing menyebutkan bahwa pada tahun 2016 terjadi 74 komplain pasien dimana 43 komplain terkait dengan farmasi $(58,10 \%)$ dan tahun 2017 sebanyak 46 komplain pasien dimana 21 komplain terkait dengan farmasi $(45,65 \%)$.

Berdasarkan wawancara yang dilakukan dengan beberapa petugas farmasi menyebutkan bahwa pelayanan farmasi rawat jalan masih lama dikarenakan ketidakseimbangan antara jumlah resep yang dilayani dengan jumlah petugas. Sedangkan wawancara yang dilakukan pada beberapa pasien di poliklinik rawat jalan menyebutkan bahwa waktu tunggu obat jadi masih lama sehingga menyebabkan bebebrapa pasien menjadi tidak puas dan akhirnya mengajukan komplain ke bagian Humas Marketing rumah sakit.

Berdasarkan hal tersebut perlu dilakukan penelitian untuk menganalisis kebutuhan tenaga kerja berdasarkan beban kerja di farmasi dan kendala dalam pemenuhan jumlah tenaga yang ideal.

\section{METODE PENELITIAN}

Penelitian ini merupakan penelitian deskriptif kualitatif dengan melakukan observasi secara langsung dengan metode time motion study untuk mengetahui beban kerja yang ada di farmasi dan melakukan wawancara mendalam pada informan. Informan utama (diberikan kode IU) pada penelitian ini yaitu apoteker penanggungjawab sebagai kepala instalasi farmasi dan tenaga teknis kefarmasian yang melakukan kegiatan pelayanan farmasi, sedangkan yang merupakan informan triangulasi (diberikan kode IT) yaitu kepala seksi penunjang medis, kepala bidang kepegawaian dan direktur rumah sakit.

Pengambilan data dilakukan dengan observasi secara langsung menggunakan form observasi time and motion study untuk mengetahui waktu kerja dan aktivitas kerja di instalasi farmasi serta melakukan wawancara mendalam terhadap para informan.

Analisis data dengan menggunakan metode WISN berdasarkan data yang didapat selama observasi. Langkahlangkah untuk melakukan perhitungan tenaga dengan metode WISN adalah sebagai berikut ${ }^{4,5,6,7}$ : (1) Menentukan unit kerja yang akan diamati. (2) Menentukan aktivitas kerja pada unit. (3) Menghitung waktu kerja tersedia (WKT).

Menghitung standar beban kerja yang merupakan kuantitas beban kerja pokok (aktivitas produktif) yang dihitung selama satu tahun untuk tiap kategori SDM. (5) Menghitung standar kelonggaran yang merupakan kegiatan atau aktivitas yang tidak berhubungan dengan pelayanan pasien (6) Perhitungan kebutuhan tenaga dengan metode WISN. Sedangkan untuk data hasil wawancara dilakukan kategorisasi data, verifikasi data dan menarik kesimpulan.

Penelitian ini sudah mendapatkan persetujuan Ethical Clearence nomor 234/EA/KEPK-FKM/2018 yang diterbitkan oleh Komite Etik Penelitian Kesehatan Fakultas Kesehatan Masyarakat Universitas Diponegoro.

\section{HASIL DAN PEMBAHASAN}

Instalasi farmasi RS. Permata medika dibagi menjadi beberapa unit fungsional antara lain pelayanan farmasi rawat jalan, farmasi rawat inap (satelit), dan gudang farmasi. Sumber daya manusia yang ada di farmasi sebanyak 22 orang yang terdiri 
dari 5 apoteker (dimana 1 apoteker sebagai kepala instalasi farmasi), 15 tenaga kefarmasian dan 2 tenaga gudang farmasi. Semua tenaga tersebut sudah memiliki kompetensi yang ssuai dan perijinan untuk melakukan pekerjaan kefarmasian.

Jumlah resep yang dilayani di unit farmasi rawat jalan dan di farmasi rawat inap (satelit) diamati dan dicatat selama dilakukan pengamatan.

Pada instalasi rawat jalan diketahui bahwa pelayanan resep paling tinggi terdapat pada hari kamis dengan total resep yang dilayani sebanyak 582 resep dengan puncak pelayanan resep terdapat pada jam 10 sampai dengan jam 12 untuk shif pagi dan puncak pelayanan resep pada jam 18 sampai jam 20 untuk shif siang. Hal ini disebabkan karena dokter yang melakukan praktek di poliklinik sudah lebih banyak.

Sedangkan pada instalasi rawat inap diketahui bahwa pelayanan resep paling tinggi sekitar jam 9 sampai dengan jam 11 dikarenakan pada jam tersebut dokter spesialis sudah melakukan visite pasien dan perawat mulai menurunkan resep dalam bentuk KPPO ke farmasi rawat inap (satelit).

Observasi dilakukan untuk mengetahui aktivitas yang ada di unit farmasi dan kemudian dihitung rerata waktu kerja tiap aktivitas (baik aktivitas produktif dan aktivitas non produktif) yang akan digunakan untuk menentukan standar beban kerja dan standar kelonggaran serta Waktu Kerja Tersedia (WKT) sebanyak 2.072 jam yang kemudian dikonversi menjadi 124.320 menit per tahun.

Salah satu standar beban kerja yang didapatkan pada penelitian ini Standar beban kerja untuk membuat obat racikan di instalasi farmasi sebesar 24.864 kali setahun dengan waktu pengerjaan obat racikan rata-rata 5 menit. Berbeda dengan penelitian lain yang dilakukan di instalasi farmasi RS. Grha Permata Ibu dimana standar beban kerja pembuatan obat racikan sebesar 12.054 dengan waktu pengerjaan obat racikan rata-rata 10 menit 8. Hal ini diakibatkan karena perbedaan dari WKT yang ada di masing-masing rumah sakit dan perbedaan waktu pengerjaan obat racikan.

Standar kelonggaran farmasi rawat jalan sebesar 0,20 dengan 7 aktivitas non produktif. Standar kelonggaran farmasi satelit (rawat inap) sebesar 0,23 dengan 7 aktivitas non produktif yang sama dengan rawat jalan. Sedangkan standar kelonggaran gudang farmasi sebesar 0,11 dengan 4 aktivitas non produktif. Pada penelitian lain didapatkan standar kelonggaran sebesar 0,18 dengan 7 aktivitas non produktif ${ }^{9}$. perbedaan ini disebabkan karena perbedaan waktu masing-masing aktivitas non produksi dan sebarapa banyak aktivitas tersebut dilakukan.

Perhitungan kebutuhan tenaga dengan metode WISN diperlukan data meliputi waktu kerja tersedia (WKT), kuantitas kegiatan pokok (produktif), standar beban kerja, dan standar kelonggaran yang dihitung selama satu tahun ${ }^{10,11}$. Kebutuhan tenaga farmasi rawat jalan adalah 11 orang nanun saat ini jumlah tenaga yang ada pada farmasi rawat jalan sebanyak 9, sehingga kekurangan 2 tenaga. Ratio WISN sebesar 0,8 yang berarti bahwa tiap tenaga hanya mampu memenuhi beban kerja sebesar 80 persen.

Kebutuhan tenaga farmasi rawat inap (satelit) sebanyak 11 orang dengan kondisi saat ini, tenaga yang ada di farmasi rawat inap (satelit) sebanyak 10 orang. Ratio WISN sebesar 0,9 yang berarti tiap tenaga hanya mampu memenuhi beban kerja sebanyak 90 persen. Kebutuhan tenaga gudang farmasi sebanyak 3 orang namun jumlah tenaga gudang farmasi saat ini hanya berjumlah 2 orang sehingga masih kekurangan 1 tenaga. Ratio WISN sebesar 0,6 yang berarti tiap tenaga hanya mampu memenuhi beban kerja sebanyak 60 persen.

Proses wawancara mendalam dilakukan pada dua kelompok informan, yaitu informan utama (terdiri dari kepala instalasi farmasi dan tenaga teknik kefarmasian) dan informan triangulasi (terdiri dari kepala seksi penunjang medis, 
kepala bidang kepegawaian, dan direktur rumah sakit) yang diperlukan untuk melakukan uji silang terhadap hasil wawancara yang didapatkan dari informan utama $^{12,13}$.

Variable masukan dalam manajemen ketenagaan pada instalasi farmasi adalah sebagai berikut :

\section{Sumber Daya Manusia}

Sumber daya manusia merupakan salah satu sumber daya yang terdapat dalam suatu organisasi yaitu meliputi semua orang yang melakukan aktivitas $^{14}$. Tenaga yang ada dalam pelayanan farmasi meliputi apoteker, tenaga teknis kefarmasian, dan tenaga farmasi lain ${ }^{15}$. Apabila jumlah tenaga tidak terpenuhi dengan baik dan kualitas SDM sesuai dengan standar yang ditetapkan maka mutu pelayanan yang dihasilkan akan tidak sesuai dengan yang diharapkan ${ }^{16}$.

Hasil wawancara dengan informan utama mengatakan masih terjadi kekurangan tenaga baik tenaga apoteker atau tenaga teknis kefarmasian. Namun hasil yang berbeda didapatkan dari informan triangulasi yang mengatakan bahwa hanya tenaga apoteker saja yang kurang namun tenaga teknis kefarmasian masih cukup jika dibandingkan dengan jumlah resep yang ada. Hal ini terdapat dalam kutipan sebagai berikut.

"Untuk apoteker saat ini masih kurang 4 dari yang dipersyaratkan sesuai klasifikasi rumah sakit dan masih kurang tenaga assisten apoteker sehingga apoteker yang ada bisa bertugas sebagai assisten apoteker." (IU1)

"farmasi rumah sakit masih mempunyai kekurangan jumlah apoteker yang seharusnya 8 tapi saat ini baru ada 5 orang. Untuk petugas farmasi selain apoteker dirasakan sudah cukup sesuai." (IT1)

Tenaga pada instalasi farmasi harus mempunyai latar belakang pendidikan yang sesuai dengan kompetensinya dan harus mempunyai surat ijin untuk dapat melakukan kegiatan kefarmasian ${ }^{17,18}$. Tenaga yang ada saat ini memiliki latar pendidikan dan kompetensi yang sesuai untuk melakukan pelayanan farmasi dan semuanya sudah mendapatkan ijin dari instansi terkait.

2. Kebijakan Rekruitmen, Penempatan dan Distribusi Tenaga

Dalam manajemen sumber daya manusia salah satu kegiatan adalah mengatur jumlah kebutuhan tenaga dengan melakukan penempatan dan pendistribusian ketenagaan pada suatu organisasi ${ }^{19,20}$.

Standar prosedur operasional (SPO) dan pedoman yang mengatur mengenai ketenagaan sudah ada dan dikelola oleh bagian ketenagaan. Namun pelaksanaannya masih belum sesuai dengan SPO dan pedoman yang sudah dibuat. Pernyataan ini sama seperti yang dikemukakan oleh informan sebagai berikut.

"SPO dan Pedoman rekruitmen tenaga farmasi sama dengan proses rekruitmen tenaga yang lain, tapi untuk penempatan dan distribusi tenaga sepertinya belum ada ya." (IU1)

"Sudah ada kebijakan untuk rekruitmen tenaga dan sudah dijalankan sesuai SPO. Tapi memang untuk proses penempatan dan distribusi tenaga masih belum sesuai dengan SPO/Pedoman yang ada." (IT3)

Beberapa kebijakan ketenagaan yang ada di farmasi antara lain SPO dan Pedoman tentang penerimaan karyawan, penetapan karyawan, pola ketenagaan dan evaluasi karyawan

3. Beban Kerja Farmasi

Perhitungan beban kerja farmasi perlu memperhatikan faktor yang berpengaruh pada kegiatan yang dilakukan salah satunya adalah jumlah resep yang dilayani riap harinya ${ }^{18}$. 
Menurut informan utama didapatkan ketidaksesuaian antara volume pekerjaan yang meningkat dikarenakan banyaknya resep yang dilayani dengan jumlah tenaga. Namun berbeda dengan yang disampaikan oleh informan triangulasi dimana peningkatan jumlah resep masih dapat teratasi dengan jumlah tenaga saat ini.

"sekarang ini jumlah pasien semakin meningkat tiap tahunnya pak. Kondisinya menjadi tidak sesuai dengan jumlah tenaga farmasi yang ada. Untuk mengatasi kekurangan tenaga kami biasanya melemburkan petugas farmasi." (IU1)

"jumlah tenaga farmasi sekarang jika dibandingkan dengan jumlah resep yang dilayani masih mencukupi, pengaturan tenaga dalam hal penjadwalan petugas masih bisa mengatasi jumlah resep yang semakin meningkat." (IT2)

\section{Sarana dan Prasarana}

Instalasi farmasi rumah sakit memerlukan kelengkapan sarana dan prasarana agar pelayanan farmasi yang diberikan kepada pasien dapat berjalan efektif dan efisien dengan selalu memperhatikan keselamatan pasien ${ }^{18,21}$.

Semua informan mengatakan bahwa sarana dan prasarana sudah sesuai untuk melakukan kegiatan pelayanan farmasi namun untuk ruang farmasi rawat inap masih terlalu kecil dan sempit sedangkan jumlah obatobatan yang disimpan terlalu banyak. Hal ini dapat terlihat dari transkrip wawancara berikut.

"Tempat farmasi satelit masih kurang luas pak. Padahal obat-obat yang ditaruh di farmasi satelit banyak karena melayani kebutuhan dari IGD dan rawat inap. Jadi susah ngatur penempatan obat-obatan." (IU5)

"Kebutuhan sarana dan prasarana sudah sesuai dengan kebutuhan untuk melakukan pelayanan kefarmasian. Kalau pasien semakin banyak dan jumlah peralatan sudah kurang memadai ada kemungkinan untuk menambah peralatan yang ada. Untuk ruang farmasi satelit memang termasuk sempit karena jumlah obatobatan yang disimpan cukup banyak sehingga ada wacana untuk farmasi satelit untuk dipisah menjadi dua unit farmasi lain, farmasi rawat inap dan farmasi satelit." (IT1)

\section{Kendala Dalam Pemenuhan Tenaga}

Apabila jumlah tenaga tidak terpenuhi dengan baik dan kualitas SDM sesuai dengan standar yang ditetapkan maka mutu pelayanan yang dihasilkan akan tidak sesuai dengan yang diharapkan ${ }^{11}$.

Pemenuhan kecukupan tenaga berdasarkan beban kerja pada instalasi farmasi masih mengalami beberapa kendala yaitu adanya efisiensi yang dilakukan rumah sakit untuk menekan biaya yang dikeluarkan dan waktu kerja petugas farmasi masih belum efektif dikarenakan petugas bekerja setelah ada resep yang dilayani yakni menunggu pelayanan pasien di poliklinik.

Rumah sakit saat ini bekerja sama dengan vendor IT dalam membuat system informasi manajemen (SIM) RS baru yang diharapkan dapat mempermudah dan membantu tenaga farmasi melakukan pekerjaan/aktivitas sehari-hari. Hal tersebut dapat diketahui dari transkrip wawancara berikut.

"Kebijakan pemilik RS sekarang ini adalah efiseinsi biaya. Sedangkan penambahan tenaga akan meningkatkan cost RS, jadi untuk penambahan tenaga memang belum menjadi jalan keluar untuk kekurangan tenaga. Beliau meminta untuk meningkatkan efektifitas kerja karyawan dulu." (IT1)

" $R S$ dan vendor IT sedang membuat SIMRS yang baru yang disesuaikan dgn kondisi RS. Nantinya SIMRS ini akan banyak membantu tenaga-tenaga yang ada dalam melakukan aktifitas pekerjaan sehari-hari." (IT2) 


\section{KESIMPULAN}

Hasil penelitian terkait analisis kebutuhan tenaga berdasarkan beban kerja yang ada di instalasi farmasi RS. X, Semarang diketahui bahwa instalasi farmasi masih mengalami kekurangan tenaga. Unit farmasi rawat jalan kekurangan tenaga sebanyak 2 orang dengan ratio 0,8 (tiap tenaga farmasi hanya mampu memenuhi 80 persen beban kerja), farmasi rawat inap (satelit) kekurangan 1 tenaga dengan ratio WISN 0,9 (tiap tenaga hanya mampu memenuhi 90 persen beban kerja), dan gudang farmasi kekurangan 1 tenaga dengan ratio WISN sebesar 0,6 (tiap tenaga hanya mampu memenuhi 60 persen beban kerja).

Pemenuhan jumlah tenaga ideal sesuai dengan perhitungan metode WISN masih sulit untuk dilakukan. Hal ini disebabkan adanya kebijakan pemilik RS untuk melakukan efisiensi biaya RS dan waktu kerja instalasi farmasi yang masih belum efektif. Manajemen rumah sakit perlu mengambil alternatif pemecahan masalah terhadap kekurangan tenaga yang ada. Beberapa alternatif yang dapat dilakukan adalah dengan pengaturan penjadwalan shif kerja, melakukan penambahan sarana dan prasarana yang diperlukan, serta membuat program jangka panjang untuk perbaikan pelayanan di instalasi farmasi.

\section{UCAPAN TERIMA KASIH}

Penulis mengucapkan banyak terima kasih kepada RS. X dan semua informan yang telah berpartisipasi pada penelitian ini.

\section{DAFTAR PUSTAKA}

1. Pemerintah Republik Indonesia, 2009, Undang Undang Republik Indonesia Nomor 36 Tahun 2009 tentang Kesehatan. Jakarta: Pemerintah Republik Indonesia

2. Ilyas, Y. Perencanaan SDM Rumah Sakit, Teori, Metode, dan Formula. Cetakan ketiga. Jakarta: Penerbit FKM UI Depok; 2011.
3. Menteri Kesehatan Republik Indonesia, 2014, Peraturan Menteri Kesehatan Nomor 56 Tahun 2014 tentang Klasifikasi dan Perijinan Rumah Sakit. Jakarta: Departemen Kesehatan.

4. World Health Organization. 2010, WISN (Workload Indicators of Staffing Need. User manual.: p 12-29.

5. Hagopian, Amy, et al. "Applying WHO's 'workforce indicators of staffing need'(WISN) method to calculate the health worker requirements for India's maternal and child health service guarantees in Orissa State." Health policy and planning 27.1 2011: 11-18.

6. Pandey, Anuja Awadh, and Swati Chandel. "Human resource assessment of a district hospital applying WISN method: Role of laboratory technicians." International Journal of Medicine and Public Health 3.4. 2013: 267-270.

7. NM, Ravhengani, and Mtshali, MG. "Implementing workload indicators of staffing need (WISN) tool to determine human resources in primary health care settings in South Africa: a concept analysis. " IOSR Journal of nursing and health science 6. 6. 2017: 65-73.

8. Verawaty. Analisis Kebutuhan Tenaga Kefarmasian Di Instalasi Farmsi Rumah Sakit Graha Permata Ibu. Jurnal Ilmiah Ibnu Sina. 2017: 313326.

9. Krisna, Melfita. Analisis Beban Kerja dan Kebutuhan tenaga Di Instalasi Farmasi Rumah sakit Jiwa Daerah Provinsi Lampung Tahun 2012. (Tesis). Jakarta: Universitas Indonesia; 2012.

10. Shivam, Swapnil, et al. "Nursing personnel planning for rural hospitals in Burdwan District, West Bengal, India, using workload indicators of staffing needs." Journal of health, population, and nutrition 32.4. 2014: 658.

11. Musau, P., et al. "Workload Indicators of Staffing Need method in 
determining optimal staffing levels at Moi Teaching and Referral Hospital." East African medical journal 85.5. 2008: 232-239.

12. Ghozali I. Aplikasi Analisis Multivariat dengan Program SPSS. Semarang: Badan Penerbit Universitas Diponegoro; 2006.

13. Bungin, B. Metodologi Penelitian Kualitatif. Jakarta: Raja Grafindo Persada; 2002.

14. Azwar, Azrul. Pengantar Administrasi Kesehatan: Edisi Ketiga. Jakarta: Binarupa Aksara; 1996.

15. Hasibuan, Malayu. Manajemen Sumber Daya Manusia. Cetakan keenambelas. Jakarta: PT. Bumi Aksara; 2012.

16. Donabedian, A. Basic Approaches to Assesment : Structure, Process, and Outcome. The Definition Quality and Approaches Its Assesment Health Administration Press; 1980.

17. Pemerintah Republik Indonesia, 2009, Peraturan Pemerintah Republik Indonesia Nomor 51 Tahun 2009 tentang Pekerjaan Kefarmasian. Jakarta: Pemerintah Republik Indonesia.

18. Menteri Kesehatan Republik Indonesia, 2004, Keputusan Menteri Kesehatan Nomor 1197/MENKES/SK/X/2004 tentang Standar Pelayanan Farmasi Di Rumah Sakit. Jakarta: Departemen Kesehatan.

19. Marwansyah. Manajemen Sumber Daya Manusia. Bandung: Penerbit ALFABETA; 2010.

20. Siagian S. Manajemen Sumber Daya Manusia. Cetakan kelima belas. Bumi aksara; 2008.

21. Sekretariat Jendral Republik Indonesia, 2007, Pedoman Sarana dan Prasarana Rumah Sakit. Jakarta: Departemen Kesehatan. 